\title{
Development of Website Model of North Sulawesi Province Tourist Attraction in Multi User
}

\author{
Yonatan Parassa \\ Department of Information \\ Technology \\ Manado State Polytechnic
}

\author{
Mex U. Pesik \\ Department of Tourism \\ Manado State Polytechnic
}

\author{
Nathaniel L. Bijang \\ Department of Information \\ Technology \\ Manado State Polytechnic
}

\begin{abstract}
The province of North Sulawesi has many tourist attractions and some of them are world class tourist destinations. Unfortunately, North Sulawesi province does not yet have a tourism website that can be accessed by information seekers to get a lot of information about tourism.
\end{abstract}

The purpose of this research is to develop the stages of the analysis of the tourist system model in north sulawesi province, where the research focuses on multi user data inputs from the terminals or workstations located in the north sulawesi provincial government. By using waterfall system development method, data collection using observation technique, interview and literature.

The result of this research is the development of the previous system that is the model of tourist website in the province of north sulawesi where the district and city operators within the scope of the province of north sulawesi can input the proposed tourism data directly on the system in a multi user way, because the previous system data tourism is collected manually for input by provincial operators. Thus there is significant efficiency.

\section{Keywords}

Model development, tourist attraction, multi user

\section{INTRODUCTION}

North Sulawesi province is located on the northern tip of Sulawesi Island with its capital located in Manado city. Viewed from the geographical location of North Sulawesi lies on the 0.300-4.300 North Latitude (LU) and 1210-1270 East Longitude (BT). His position stretches from east to west with the most areas north is Sangihe and Talaud Islands, where the archipelagic region is bordered directly with neighboring Philippines. The total area of North Sulawesi is 13,851.64 km2 [1]. North Sulawesi Province has 15 (fifteen) regencies and cities.

Today, tourism is one of the biggest and dynamically developing sectors of economic activities. Its high expansion and growth rates, infrastructure amplification, and introduction of new management and educational experience actively acts various sectors of economy, which positively contribute to the social and economic development of the country as a whole. According to recent statistics, world's $10 \%$ income is coming from tourism and employs almost one tenth of the world's workforce [2].

Tourism is one of the State's major businesses. It has played a significant job for developing the financial system, particularly in the area of the Valley and Ladakh. The industry has given jobs to a very large number of people and generated economic activities in the primary, secondary and tertiary sectors in the State, which owes dependence to a large extent to this industry [3].
The Internet is used for many commercial and noncommercial solutions to provide content or services to multiple users [6]

Tourism Department makes information media such as Tourist Information center and then made digitally connected to social media with Tourist Information Service content which are linked to social media and websites and accessible to tourists and perpetrators tourism [7]

Tourism information is an important need for information seekers in the capacity of visitors and prospective visitors in North Sulawesi Province [8]

With an area of $13,851.64 \mathrm{~km} 2$, and has 15 (fifteen) city districts, North Sulawesi province needs a website to be able to promote tourism and tourism website can be done efficiently. The model of tourism website of the province of North Sulawesi, which only supports data input only from the level of provincial operators is felt to require development considering the area and the number of districts and cities owned by the province of North Sulawesi. The development of a website model of a tourist attraction in the province of north sulawesi that can support multi-user data input from the district or city level is a necessity and also a very efficient thing compared to the data input system only from provincial level operators.

\section{LITERATUR REVIEW}

The Internet is a global communications network communication that connects the whole computers in the world despite different operating systems and machines[4].

One of the most wide spread methods of providing information over the Internet is via the World Wide Wweb (the Web). The Web consists of a subset of the computers connected to the Internet [5].

A multi-user system, associated with a first user and a plurality of non-first users each having respective client systems associated therewith and wherein each client system is connected to a server system through a computer network, the system providing multi-user interactive environments on web pages served by the server system [6]

A use case describes a specific usage of the system by one or more actors. An actor is a role that a user or another system has. The objective of use case modeling is to identify and describe all the use cases that the actors require from the system [9].

\section{DATA AND METHOD}

Research uses several methods in data collection, 1). Observation method is a technique or approach to obtain primary data by observing directly the data object. 2). interview method is a two-way communication to get data from the respondent [10], 3). Library study is conducted to 
enrich the knowledge of the various concepts that will be used as a basis or guidance in the research process. Library study in this data collection technique is a kind of secondary data that is used to assist the research process, by collecting information contained in newspaper articles, books, and scientific papers on previous research [11].

\section{RESULT AND DISCUSSION}

The development model of the previous system is on the input data. The former system inputs tourism data at the provincial level. The proposed new system, data input can be done by district and city operators within the province of north sulawesi. If there is data that should be updated on the tourism website, there is no need to retrieve the data manually because the data can be inputted by the operator from each district or city. Thus there is a significant efficiency. Considering that the Province of North Sulawesi has 15 (fifteen) districts and cities.

The following use case diagram represents how the data input can also be done by the operators of the regencies and cities in the working area of the province of north sulawesi.

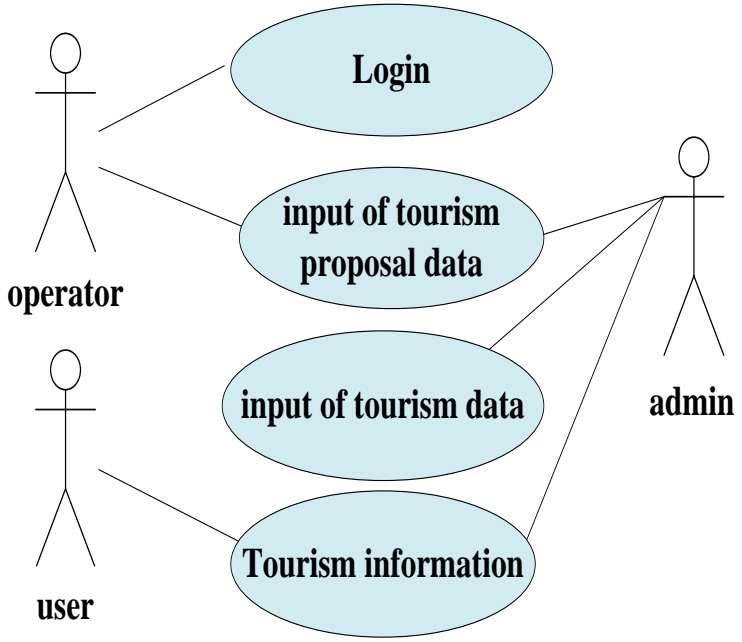

Fig 1: Use case input data by operators of the regencies

\section{CONCLUSION}

Development of website model of tourist attraction of north sulawesi province which previously all tourism data inputted by provincial operators, in this research the latest data input proposal system can be done by operators at district and city level, thus there is efficiency. For the future this research

\section{ACKNOWLEDGEMENTS}

Thanks to the research, technology and higher education ministry, which has provided funding support through research directorate and community service, also to Manado State Polytechnic and friends in Informatics Engineering Department

\section{REFERENCES}

[1] Machmud, M. (2014). Analisis Kinerja Keuangan Daerah Di Provinsi Sulawesi Utara Tahun 2007-2012. Jurnal berkala ilmiah efisiensi, 14(2).

[2] Joshi, A. A., Dube, S. S., Kadam, O. R., Shilamkar, A. M., \& Bhagat, G. (2016). Tourist Application for Selecting Packages: A Survey. International Journal of Computer Applications, 139(5).

[3] Shastri, S., Sharma, A., \& Mansotra, V. (2015). A Model for Forecasting Tourists Arrival in J\&K, India International Journal of Computer Applications, 129(15), 32-36.

[4] Ahmadi, C., \& Hermawan, D. (2013). E-business \& e-commerce. Yogyakarta: Andi.

[5] Able, S. L., \& Martin, R. S. (2010). U.S. Patent No $7,665,064$. Washington, DC: U.S. Patent and Trademark Office.

[6] Taing, L. B. (2011). U.S. Patent No. 7,958,453 Washington, DC: U.S. Patent and Trademark Office.

[7] Umami, Z. (2015). Social Strategy Pada Media Sosial Untuk Promosi Pariwisata Daerah Istimewa Yogyakarta Interaksi: Jurnal Ilmu Komunikasi, 4(2), 195-201.

[8] Parassa, yonatan. 2017. Analysis of Tourist Information System Model in North Sulawesi Province. International Journal of computer applications (IJCA), 175.

[9] Eriksson, H. E., \& Penker, M. (2000). Business modeling with UML. New York, 1-12.

[10] Jogiyanto, 2007. Sistem Informasi Keperilakuan. Edisi Revisi. Andi Offset, Yogyakarta.

[11] Martono, Nanang. 2011. Metode Penelitian Kuantitatif PT Raya Grafindo Persada. Jakarta. 